\title{
リユース材で構成された張弦クレセント構造の力学性状に関する研究 EXPERIMENTAL STUDY ON THE STATIC CHARACTERISTICS OF STRING CRESCENT STRUCTURE MADE FROM REUSABLE PARTS
}

\author{
田中 晃*
}

\begin{abstract}
Akira TANAKA
I proposed Crescent System and String Crescent Structure (SCS). Crescent System secures a reuse function, and SCS is the structure that stabilized Crescent System. I made the models of SCS of the cantilever and did an experiment and analysis. This purpose is to clarify the influence of Crescent part shape and the prestress on structural behavior of SCS. I show consideration based on the result below.

1) The stress transmission mechanism between Crescent Parts was estimated, and this mechanism was demonstrated by the experiment and the analysis.

2) I analyzed a stress, rigidly and the geometric element, and I was able to estimate the proper value of Minor arc angle.

3) Crescent part shape influences the rigidity of SCS. A mechanical role of arms is only the reduction of deformation.

4) A mechanical role of the prestress of the strings is prevention of deformation by slide, and improvement of structural performance of SCS.

5) The experimental value accorded with the analysis value in "Load-displacement"and "Load-tension of the string".
\end{abstract}

Keywards Reuse, Stress transmission mechanism, Contact, Separating, Sliding, P restress, リュース, 応力伝達メカニズム, 接触, 離間, 滑り, 初期張力

\section{1. はじめに}

「リユースシステム」は建材のスクラップ化および熱処理等に伴う 発生 $\mathrm{CO}_{2}$ の低減等が期待される。しかし, 解体後の建材は電炉メ一 カーへのリサイクルや, 構造材以外の用途に再利用される事が多く 1)，リサイクルに依存しない建材のリユース率の向上が課題となる。 本論のリユースシステムは，原料から建材に製造する前に予めリユ 一ス可能な建材を設計しておく事を前提としており，用途は，仮設 空間, 風雪に晒されない屋内展示施設, 入れ代わりの激しい大型商 業施設内の店舗等である。既往のリユースシステムは，「組立性」

「分解性」「反復性」を付加し, 組立プロセスを簡略化したものが多 いが，今後は，リユース率を高める為に使用建材の種類数を抑えな がら様々な構造形状へ再利用できる「転用性」をも考慮された組立 プロセスの導入が必要となる。

リユースシステムは，部材の生産・組立・解体・収納・運搬等の 工夫により，「(1)組立式」「(2) 可動式」「(3)非接着式」といった リユースシステムの接合方式が発生する。「(1)組立式」の例として, 災害時の応急仮設住宅 ${ }^{2}$ 等があげられ，プレハブ住宅の構法を簡略 化する事で，簡単な組立プロセスを可能にしている。「(2) 可動式」 は展開構造の接合等に使われており, この 1 例として斎藤公男らに

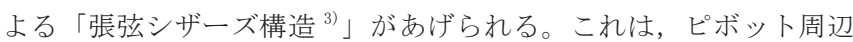
の曲げモーメント発生の回避により「構造の大規模化」と「リユー ス」との両立を図り，ピボット位置の調整により構造形状の変更を
可能にしている。「(3) 非接着式」は接着および結合箇所を極限に減 らした「接着によらない応力伝達機構」の接合であり, その 1 例と してリユースシステムへの適用を意図した「要素非接着型構造 ${ }^{4)} 」$ が山口謙太郎により提唱されている。実施例として伊東豊雄らによ る Sudare $\mathrm{e}^{5)}$ があげられ，事前にワイヤーで押出形材をつなぎ合わせ ておき, ワイヤーを緊張させただけで曲面形状屋根が安定する。異 なった形状の構造への転用も意図しているが，異なった形状の押出 形材との取替が必要となる。以上取り上げた既往のリユースシステ ムの最大の特徵は, 軽量性と組立プロセスにおける迅速性と簡易性 であるが，共通課題として「構成部材の種類を最小限に抑える」と 「梁形状や板形状等，異なった形状の構造物との間で転用できる」 との両立を満たしていない事があげられる。

本論では, その共通課題の解決を目的に, 三日月形状部品 (以下, 略称 : C 部品) とアーム材との組合せによるクレセントシステムを提 案する。次に, クレセントシステムに弦材を取り付けて安定化させ た「張弦クレセント構造」(String Crescent Structure, 以下略称： SCS）を提案する。さらに, SCS の形状を片持梁に絞り, C 部品の基本 形状, 基本形状内に中空部を設けた中空形材, アーム材の有無等に よる構造挙動の変化を検討した。最後に, 初期張力 (Prestress 以下, 略称：PS) 量に応じた SCS の構造挙動の実験的および解析的検討を 経て, SCSの力学性状およびリュースシステムへの実用性の考察を 行った。 


\section{1 クレセントシステムの構成}

本論のリユースシステムの条件を明らかにする為に, 異なった形 状の構造への転用を考慮したリユースシステムの課題を以下に示す。 (1)異なった形状の建材の導入を最小限に済ませる。

(2)ボルトの取付または取外しの地組のプロセスを最小限に済ませる。

上記（1)関しては，異なった形状の構造へ再利用する場合，使用 部材の寸法変更に伴う再加工が必要となる。再加工できない場合は, 建材搬入や不要な建材が繰り返し発生し, リユース率が低下寸る。 上記(2)は，事前に工場等でボル卜接合等を済ませる事で，地組工事 のプロセスやその所要時間を低減する事を意図する。

上記の課題を解決し，「使用部材の種類を最小限に抑える」「異 なった形状の構造物に転用できる」の両立を図る手段として，C 部 品とアーム材とを組合せたクレセントシステムを提案する (Fig. 1(a))。クレセントシステムは，アーム材による「可動式」接 合と C 部品による「非接着式」接合との組み合わせによるハイブリ ッド接合が用いられている。C 部品間の回転運動を容易にする為に, $\mathrm{C}$ 部品の両底面にアーム材を平行状態に取り付け，ボルトで固定す る。この連結作業の繰返しにより，蛇形状のクレセントシステムが 形成される。C 部品はアルミ押出形材であり, 骨梁からのヒントに よる三日月形状が用いられる(Fig. 1(b))。これは, 優弧部と劣弧部 からなる「(1)側面材」と, 中心点に設けられた「(2)貫通穴」と，中 心点から放射状に伸びた「(3)縦材」と, 縦材に対して直角に同心弧 状に配置された「(4)横材」によって構成される。「(1)側面材」はC 部品の優弧部と隣接する $\mathrm{C}$ 部品の劣弧部との応力伝達を可能にする。 「(2)貫通穴」はボルトを介して C 部品とアーム材を連結させる。「(3) 縦材」は側面材への補強により C 部品の力学性能を向上させる。「(4) 横材」は縦材の座屈防止が期待される。「(1)側面材」の形状は力学 的検討の結果に基づくが，詳細について 3.4 で述べる。さらに，側 面材に膜材や弦材等を取り付ける事が想定されるが，側面材形状が 曲面であり，これにあわせた形状の金物が必要となり，接合コスト の抑制が課題となる。この解決手段として，普遍的な接合金具を取 り付けられるように側面材の 2 箇所に「(5)扁平部」を設ける (Fig. 2)。 (a) Crescent System Parts

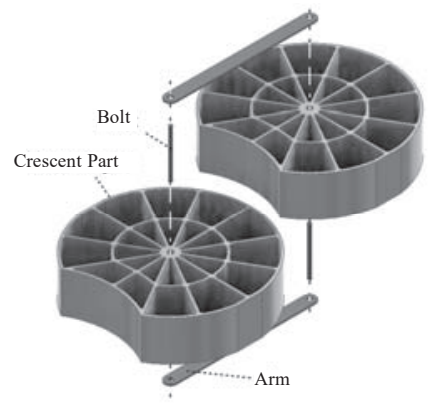

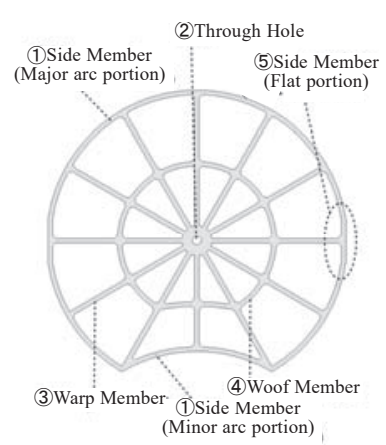

(b) Crescent Part Shape
Fig.1 Crescent System

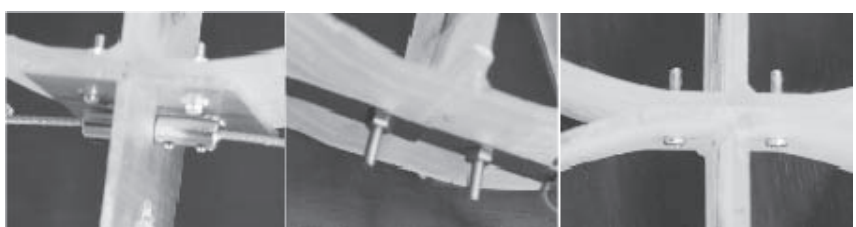

(a) Metal fittings
(b)Strings
(c)Two Crescent parts
Fig. 2 The joining method of Crescent parts

優弧部と劣弧部 (以下, 優劣弧部) との接触面には滑りや離間を許 容する非接着式接合が用いられる。ボルトを使わずに接触させるだ けなので組立プロセスにおける迅速性と簡易性の確保が期待できる。 クレセントシステムの概要図を Fig. 3 に示す。一般的な煉瓦等と 比べて C 部品は滑り落ちやすい形状を有する為, 組積工事における 落下事故のリスクが高い。この防止策として, 事前に $\mathrm{C}$ 部品の連結 材を取り付ける。特にアーム材との組合せは, クレーンや人力によ る吊りによって，策のような展開および折畳を容易にし，現場での 地組の所要時間の短縮や安全性向上を意図している。以上，アーム 材の生産的な役割を述べたが，力学的な役割に関しては 4.5 で述べ る。クレセントシステムに数種類だけの部材の導入で様々な形状一 組み立てられる。C 部品とアーム材との配置に様々なタイプが考え られ, これらに応じて「単層式」「複層式」「多段式」とに分類で きる。「単層式」は最も簡易な構成が見られる。「複層式」は, 複 数の C 部品を積層に積み上げて作られたユニットがアーム材で連結 される。「多段式」は「複層式」のユニットが階段形状に連結され

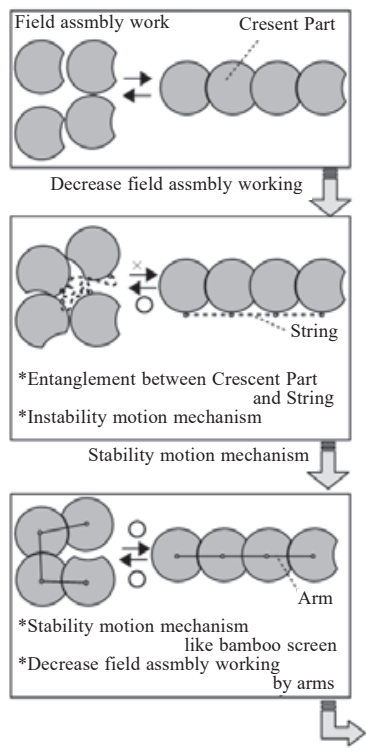

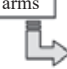

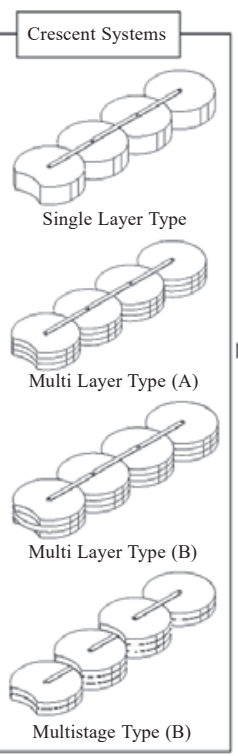

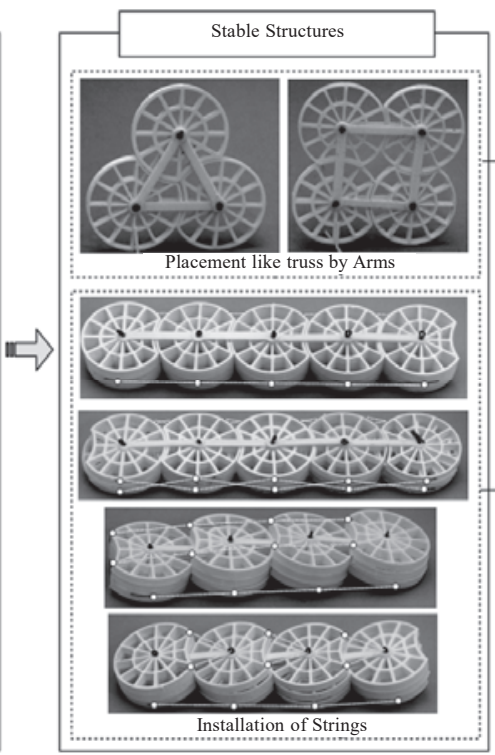

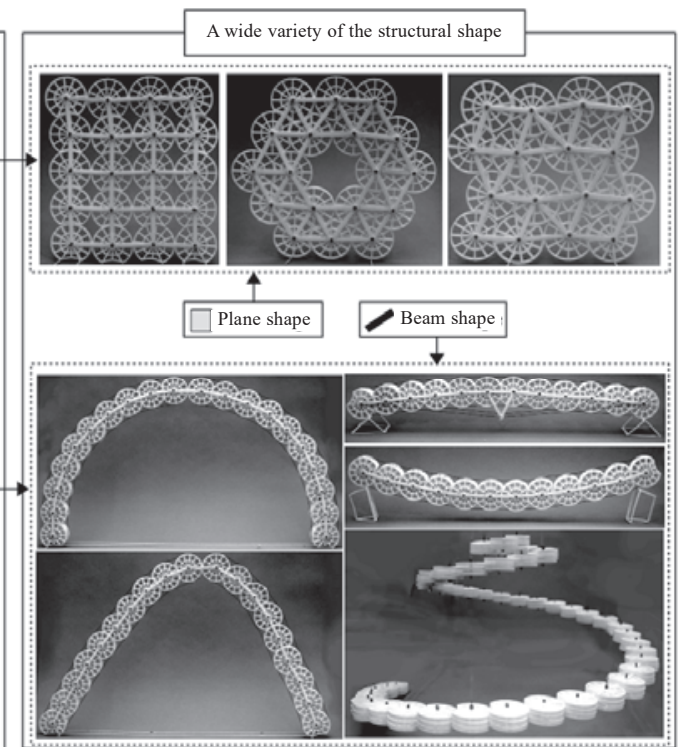

Fig.3 Development of Crescent systems 
る。「多段式」はコンパクトに折り畳めるが, 部材配置が複雑で岡 性が劣る。これに対して, 「単層式」は簡易性と剛性に優れており, 建築構造への実用性が高い(Fig. 4)。

\begin{tabular}{|c|c|c|}
\hline & Single Layer Type & Multistage Type \\
\hline \multicolumn{3}{|l|}{ Folding } \\
\hline & Bamboo screen shape & Spiral shape \\
\hline \multicolumn{3}{|l|}{ Development } \\
\hline \multirow{2}{*}{ Other feature } & Simple Structure & Complex Structure \\
\hline & $\begin{array}{l}\text { Rigidity of the stable structure } \\
\text { (High) }\end{array}$ & $\begin{array}{l}\text { Rigidity of the stable structure } \\
\text { (Less) }\end{array}$ \\
\hline
\end{tabular}

Fig.4 Comparisons with two different Crescent Systems

\section{2. $2 \operatorname{SCS}$ の提案}

単層式クレセントシステムは不安定な構造物であり,これを安定 させる為に, 各扁平部間に平行かつ連続した弦材を配置した SCS を提案する (Fig. 5)。各部材の役割として, C 部品は骨, 弦材は咲 節の安定に寄与する勒帯 ${ }^{6}$ (Fig. 6) に相当する。さらに, C 部品間 のがたつきを防止し，C 部品間の応力伝達の安定性を高める為に, 弦材に PS 導入する事を前提とする。C 部品やアーム材の寸法を変 えずに, 異なった寸法の弦材の取替だけで SCS 全体形状を変えられ る。以下, SCS の形状を片持梁に絞り, 力学的検討を行う。

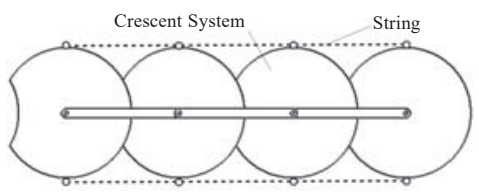

Fig.5 SCS
Fig.6 Ligament

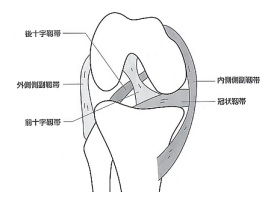

\section{SCS の応力伝達メカニズムと C 部品の基本形状}

\section{1 部品の基本形状の決定要素}

$\mathrm{C}$ 部品の基本形状は, 半径 $\mathrm{r}$ が同一である優弧と劣弧に囲まれた 三日月形状である (Fig. 7)。AB 間距離 $\mathrm{L}_{J}$ や劣弧の角度 vの数值によ って, 三日月形状の「久け」が変化する。アルミ材の押出加工のコ ンテナ径(最大外接円) $235 \mathrm{~mm}$ に基づき ${ }^{7)}$, 半径 $\mathrm{r}$ を $100 \mathrm{~mm}$ とする。 回転運動の自由度および SCS の安定性確保の考慮上, 角度 vを20 $110^{\circ}$ とし，この範囲における距離 $\mathrm{L}_{\mathrm{J}}$ を算定する為に次式を用いる。
$L_{\jmath}=2\left\{r-r\left(1-\cos \frac{v}{2}\right)\right\}$

$\mathrm{A}$ : 優弧の中心点 $\mathrm{B}$ :劣弧の中心点 $L_{J}: A B$ 間距離 $\quad r: C$ 部品の半径 $v:$ 劣弧の角度

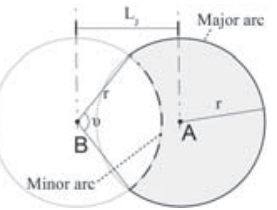

Fig.7 Basic Shape
「久け」の大きさは, 梁のスパンあたりの接合部数, 断面力を受け た SCS の応力状態や剛性等へ影響を与える。これを考慮した適正な 角度 $の$ の決定を試みる為に, 解析的検討を行う。

\section{2 SCS のC 部品間の応カ伝達メカニズムの推定}

側面材の優劣弧部間の接触面には非接着式接合が用いられている。
非接着式接合の定義の範囲は「摩擦抵抗によりせん断方向の安定状

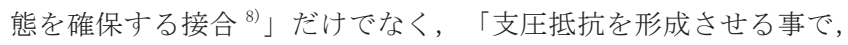
離間を部分的に発生させたにも関わらず安定状態を失わない接合」 をも含む。なお, 摩擦が接合部に及ぼす力学的な影響を推定する事 が難しい為, 本論では, 接触と離間の発生のみを考慮する。外力 $\mathrm{P}$ の作用方向は「底面の垂直力」と「側面の垂直力」が考えられるが, 外力の作用方向によって SCS の変形が異なる Fig. 8)。底面の垂直力 の場合, C 部品間にせん断力方向の滑りが生じ, アーム材が破損し SCS 全体の可動性が損失する可能性がある。これに対して, 側面の 垂直力の場合, $\mathrm{C}$ 部品間に回転方向の滑りが生じ, 弦材が力学的役 割を発揮する。この条件下のアーム材は, SCS の中立軸に近い位置 に配置されるので, 発生応力負担が小さく済ませられ, 可動性が損 失しにくい事が予想される。このような観点にたち, 以下，実験お よび解析の荷重条件を側面の垂直力に絞る。
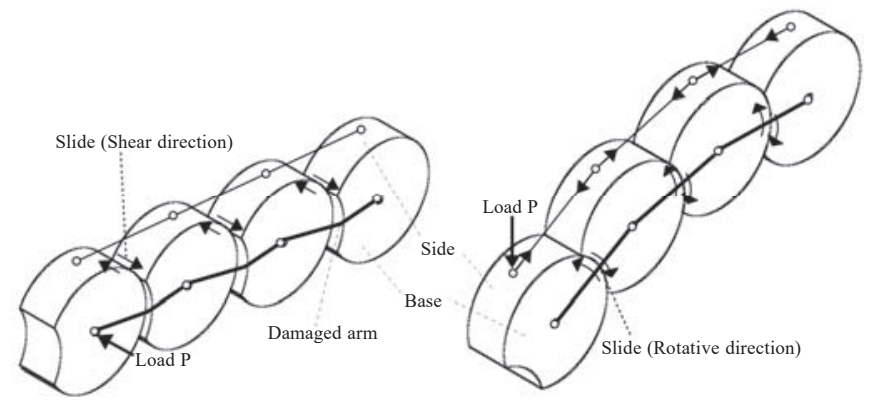

(a) Perpendicular force of the base (b)Perpendicular force of the side Fig.8 Deformation of SCS

C 部品間の接合部の妥当性等を検討する前に, 応力伝達メカニズ ムをFig. 9 に示す。弦材の PS 導入により接触面に支圧力を発生させ たモデルとし，アーム材の存在を無視した応力伝達メカニズムの推 定を行う。せん断力の伝達メカニズムにおいて, 接触面の離間発生 前では, 接触側の支圧力が増加し, 離間側の支圧力が低減するが, 弦材の軸力は発生しない。接触面の離間発生後では, 離間側の支圧 力が消失する。これに伴って, 接触面積が縮小し, 接触側の支圧力 が増大する。同時に, 接触面の離間の進行を抑える為に, 平行する 2 弦材に張力が発生する。曲げモーメントの伝達メカニズムにおい て, 張力消失前では, 2 弦材の発生軸力が接触面での回転方向滑り や発生支圧量を抑える。張力消失後では, 弦材張力 (引張側)および

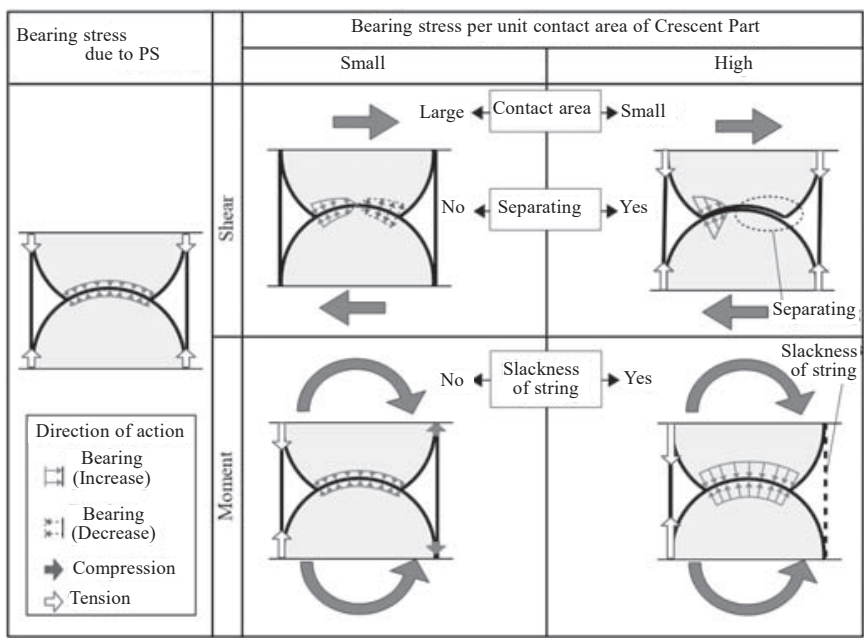

Fig.9 Stress transfer mechanism in Joint between Crescent parts 
支圧力が増大寸る。離間や張力消失の発生に応じて応力伝達メカニ ズムを推移させる事で SCS の安定性が保持される。

\section{3 数值解析概要}

数值解析モデルには Fig. 10 に示寸片持梁形状と荷重条件を用い, 数值解析ソフトウェア Autodesk Simulation Mechanicalによる 2D モデルの非線形解析を行う。荷重側の最上接合部にUnit Q を, 支点 側の最下接合部にUnit M を設定し, Unit Q ではせん断力時の, Unit M では曲げモーメント時の発生応力・変形を検討する。弦材におけ る解析条件として座屈が発生せずに中心圧縮が作用するものとし, 張力消失の有無に応じた 2 タイプのトラス要素を用いる。これらの 要素の組合せによる 4 タイプ (Q1， Q2，M1，M2）の検討用ユニットを 設定する $(\mathrm{Tab} 1 \mathrm{e} 1)$ 。接合モデルは, 接触面における摩擦の存在を無 視する条件に基づく。使用ソフトウェアのメーカーより独自に推奨 された公式 ${ }^{9)}$ に基づく接触剛性のパラメータを「Auto」に設定し (Fig. 11), 非線形解析 (荷重増分法, ステップ数=5) を行った。これ により, ステップ毎に接触剛性の数值が自動的に設定され、変位量 と応力が算定される。4 タイプの検討用ユニット毎に発生応力およ び変形を検討する為に，2載荷点に平行かつ正反対関係の集中荷重 $\mathrm{P}$ を設定する。3.1 に示す SCS の距離 $\mathrm{L}_{\mathrm{J}}$ 等が変化すると, Fig. 10 に 示す等価梁のスパン長さおよび $\mathrm{M}$ 図が変化し, 適正な角度 $\mathrm{v}$ を推定 できなくなる。そこで, 梁寸法の基準を $\mathrm{L}=1,000 \mathrm{~mm}, \mathrm{~L}_{\mathrm{P}}=550 \mathrm{~mm}$ とし， $\mathrm{L}$ と $\mathrm{L}_{\mathrm{P}}$ の寸法ばらつき(標準偏差)を最小限に抑える為に, 角度 $v$ 毎 にSCS の接合部数 J の調整を行なった (Tab1e2)。それでも, L と L の寸法のばらつきの解消は十分でない為に, 「M=50, 000Nm」に固定 された曲げモーメントから L $\mathrm{L}_{\mathrm{P}}$ で割って荷重 $\mathrm{P}$ を算定し, これをUnit M の検討用荷重 $\mathrm{P}_{\mathrm{M}}$ とした。その一方，「Q=100N」に固定されたせん 断力から荷重 $\mathrm{P}$ を算定し, これをUnit $\mathrm{Q}$ の検討用荷重 $\mathrm{P}_{\mathrm{Q}}$ とした。 各角度 $\mathrm{v}$ 毎に設定された荷重 $\mathrm{P}_{\mathrm{M}}$ および $\mathrm{P}_{\mathrm{Q}}$ の数值を $\mathrm{Tab} 1 \mathrm{e} 2$ に示す。

SCS の変位量を検討する時は, Fig. 12 に示す接合部の離間と滑り を考慮したモデルを用いる。せん断力時の変形の検討では, Unit Q の変形角 $\left(\theta_{Q}=\delta_{Q} / L_{J}\right)$ を用いる。曲げモーメント時では「C 部品自 体の変形」と「C 部品間の滑りによる変形」が発生する。「C 部品自 体の変形」には連続弾性体の力学理論に基づいた曲率 ${ }^{10)}$ が適用でき る。これに対して「C 部品間の滑りによる変形」では「骨格関節の 凹凸法則 ${ }^{11}$ 」に類似した「B 点を中心とする回転方向」の滑りが発 生し, AC と BC との距離に差異が生じる(Fig. 12 (b))。剛性が低いC 部品には, 滑りが生じる前に「C 部品自体の変形」が発生するが, 剛性が高くなるにつれ「C 部品間の滑りによる変形」の傾向が強く
なる。C 部品の適正な形状の決定要素の 1 つとして「C 部品間の滑り による変形」を重視し，「C 部品自体の変形」の影響を抑える為に 中空部を設けない基本形状による解析モデルを用いる。「C 部品間 の滑りによる変形」を考慮した適正な $\mathrm{C}$ 部品の形状を評価する為に Unit M の変形角 $\left(\theta_{\mathrm{M}}=\delta_{\mathrm{M}} / \mathrm{L}_{\mathrm{J}}\right)$ を用いる。なお, 弦材方向の変位量 $(\triangle$ $\mathrm{Y}_{Q}$ および $\left.\Delta \mathrm{Y}_{\mathrm{M}}\right)$ は, 無視できるほど微小とみなす。Fig. 12 の弦材にお ける記号 N は軸力を表す。接触面付近に発生する最大圧縮応力度は 最小主応力の最小值に基づくとし, SCS のリユース機能を保持する

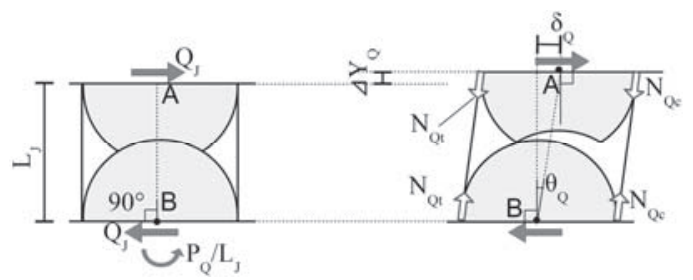

(a) Deformation of UnitQ

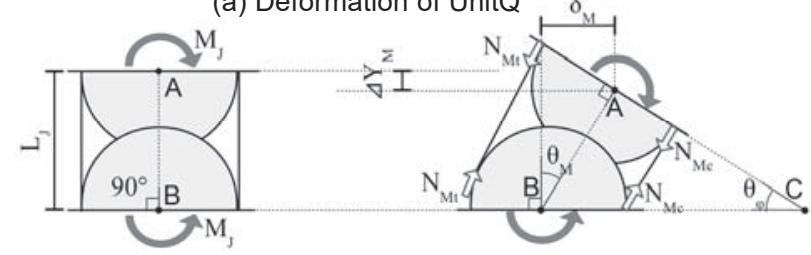

(b) Deformation of UnitM

Fig.12 Deformation by sliding and separating

条件の 1 つとして優劣弧部間の接触面付近での発生圧縮応力度を抑 える事を主眼においている。

\section{4 解析結果}

\section{(1) 変形角}

角度 $\mathrm{v}=20^{\circ}$ 時の変形角を基準とし，Q1 および M1 の変形角を $\theta_{Q}$, $\theta_{\mathrm{N}}$, 基準変形角を $\theta_{Q}, \theta_{\mathrm{M} 0}$ と表す。両者の変形角比をそれぞれ $\mathrm{R}_{Q}(=$ $\left.\theta_{Q} / \theta_{Q 0}\right), R_{M}\left(=\theta_{M} / \theta_{M_{0}}\right)$ と表す。Unit $Q$ の「角度 $v$-変形角比」を Fig. 13 (a) に示す。Q1(O) では, 角度 v が $20^{\circ}$ から $40^{\circ}$ 一と大きく なるにつれ変形角比 $\mathrm{R}_{Q}$ が抑制されていくが, 角度 $v=40^{\circ}$ を超える と変形角比 $\mathrm{R}_{Q}$ が 0.4〜0.5 に落ち着く。Q2 $(\mathrm{O})$ では, 角度 v 40〜 $60^{\circ}$ 時の変形角比 $R_{Q}$ が最も小さく抑制される。Unit M の「角度 v一変形 角比」をFig. 13(b)に示す。M1（○）では, 角度 v $=60^{\circ}$ を超えると, 変形角比 $\mathrm{R}_{\mathrm{M}}$ が抑制されていく。M2 $(\mathrm{O})$ では, 角度 vが 20 から $50^{\circ}$ へと大きくなるにつれ, 変形角比 $\mathrm{R}_{\mathbb{M}}$ が抑制されていくものの, 角度 $v=50^{\circ}$ を超えると変形角比 $R_{M}$ が増加し, 角度 $v=80^{\circ}$ 時をピークに 再び抑制の方向に転じる。M1 と M2 との比較により, 張力消失後の

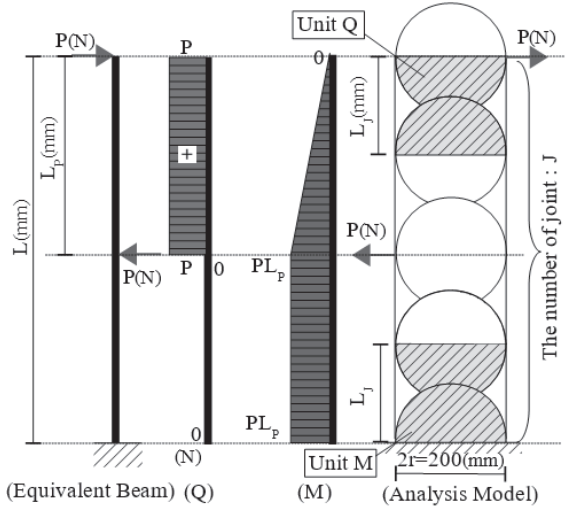

Fig.10 Analysis Model

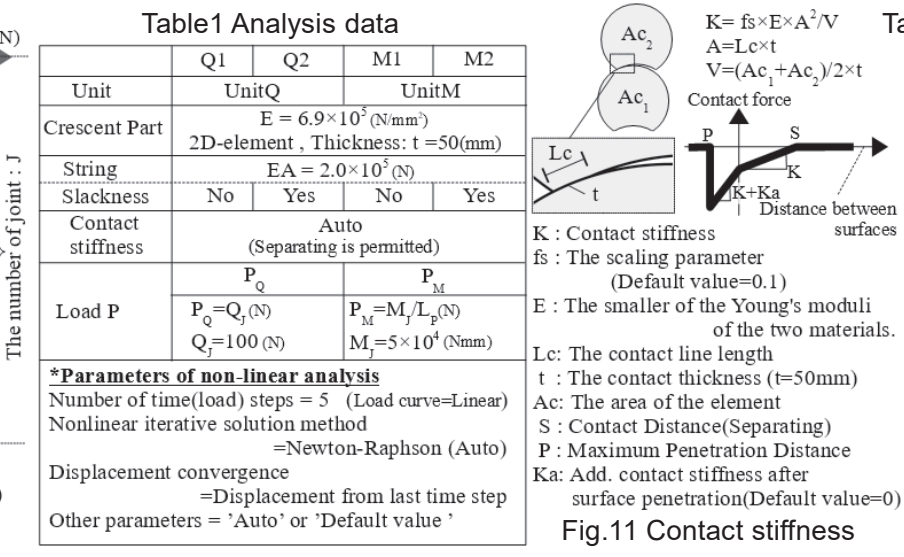

Fig.11 Contact stiffness
Table2 Analysis data by " $v$ "

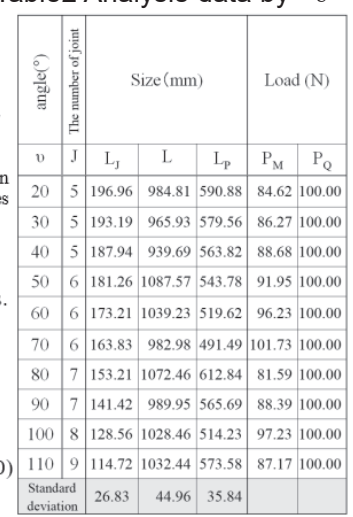


方が変形角比が増加する事が明らかとなった。ここから理解できる 事は, 剛性確保が純粋に期待される角度 vは $110^{\circ}$ であるが，接合 コストの抑制も考慮すると, 角度 v $40 \sim 60^{\circ}$ が適正となる。

\section{(2) 接触面付近の圧縮応力度}

Unit Q の「角度 $v$-最大圧縮応力度」をFig. 14 (a) に示す。張力消 失の有無に関わらず, 接触面付近に発生する最大圧縮応力度に差異 が認められない。角度 vが $20^{\circ}$ から $60^{\circ}$ へと大きくなるにつれ，最 大圧縮応力度 $\sigma_{Q}$ が抑制されていくが，角度 $v=60^{\circ}$ を超えると最大 圧縮応力度 $\sigma_{Q}$ が増加気味の傾向が見られる。Unit Mの「角度 v一最 大圧縮応力度」を Fig. 14 (b) に示す。M1 と M2 との比較により, 張力 消失後の方が最大圧縮応力度が増加寸る事が明らかとなった。角度 v $=60^{\circ}$ を下回ると, 最大圧縮応力度が抑制される傾向が見られる。 以上をまとめると, 角度 $\mathrm{v}$ が小さい時はせん断力による圧縮応力度, 角度 v が大きい時は曲げモーメントによる圧縮応力度の発生量が大 きく, 両者による圧縮応力度を抑える観点にたてば，適正な角度 v は $40 \sim 60^{\circ}$ となる。接触面付近の圧縮応力度の低減は「めり込み」 による C 部品の破損防止につながる事が期待される。

\section{(3) 弦材の軸力}

Unit Q の「角度 v一弦材軸力」を Fig. 15 (a) に示す。張力消失の有 無に関わらず, 両者の差異が認められず, 角度 $v=90^{\circ}$ の時, 弦材の 発生張力が最小值に抑えられる。Unit M の「角度 v一弦材軸力」を Fig. 15 (b) に示す。張力消失を考慮した M2 の場合, 角度 ৩の数值に 関わらず, 発生軸力量に変化が見られない。M1 の場合, 角度 $v=40^{\circ}$ では引張力が, 角度 $v=90^{\circ}$ では圧縮力が強く作用寸る。張力消失等 の回避への観点にたてば, 角度 $v=90^{\circ}$ による C 部品の形状を用いる 事は得策ではなく, 適正な角度 vは $40 \sim 60^{\circ}$ となる。

以上の変形角比, $\mathrm{C}$ 部品の圧縮応力度および弦材の軸力を抑え, SCS の構造性能の向上を図る為に, 適正な角度 vを $40 \sim 60^{\circ}$ とする。 さらに，4章で述べる縦材の配置形状をも考慮し，以下，角度 vを

(a) $v=20^{\circ}$

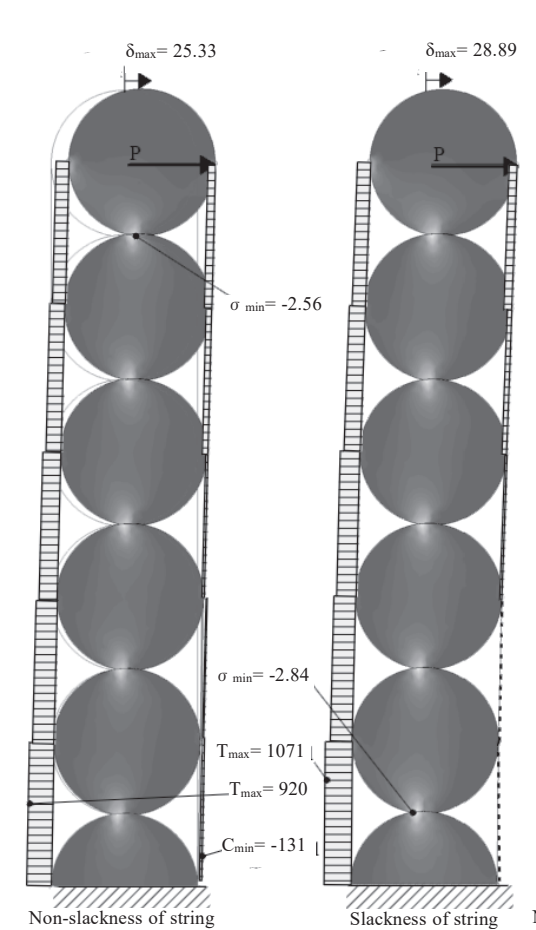

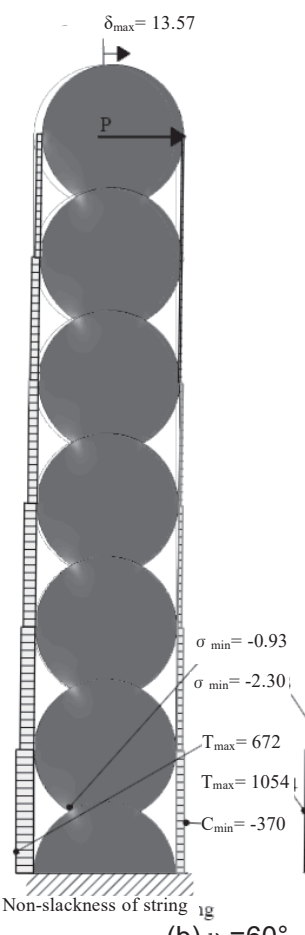

(b) $v=60^{\circ}$

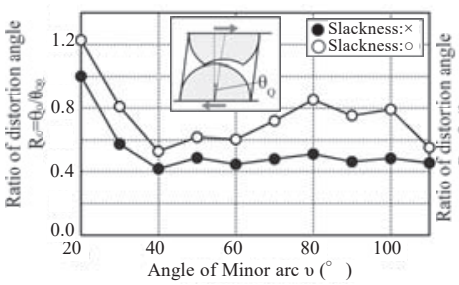

(a) Unit $Q$

Fig.13 An

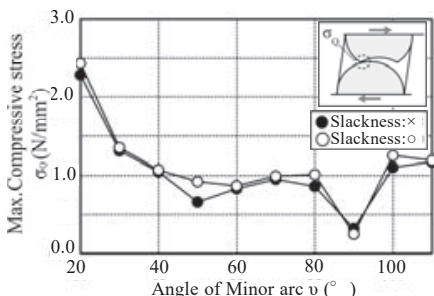

(a) Unit Q

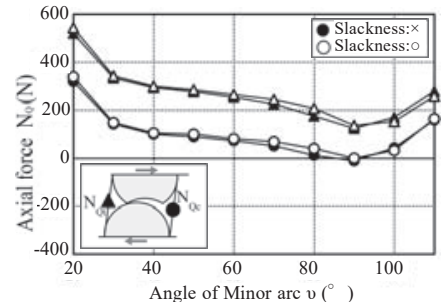

(a) Unit $Q$

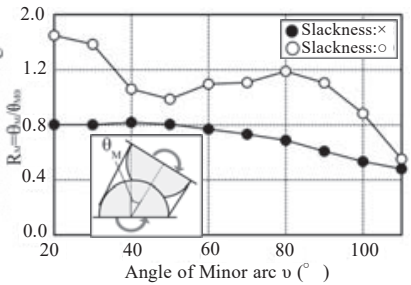

(b) Unit M
Fig.15 Angle of Minor arc - Axial force

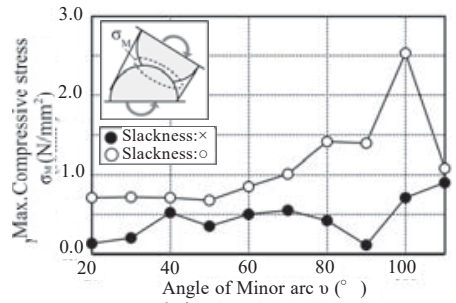

(b)Unit M

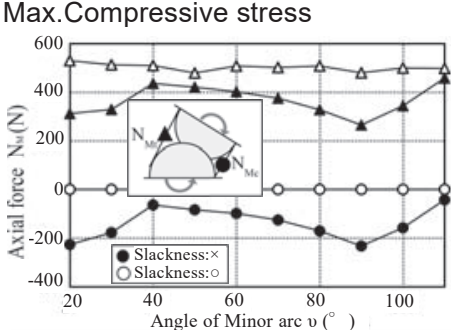

(b)Unit M

$60^{\circ}$ に指定する事にする。

\section{(4) 一点集中荷重状態の SCS の構造性能の比較}

基本形状の違い（角度 $v=20^{\circ}, 60^{\circ}, 100^{\circ}$ ) による 3 種類の $\mathrm{C}$ 部品 を取り上げ, Fig. 16 に示す 1 点集中荷重状態の SCS を対象に解析的 検討を行った。張力消失の有無に関わらず, (a) と比べて, (b) (c) の方が水平変位量が抑えられる。(b) (c) の比較上, C 部品の最大圧

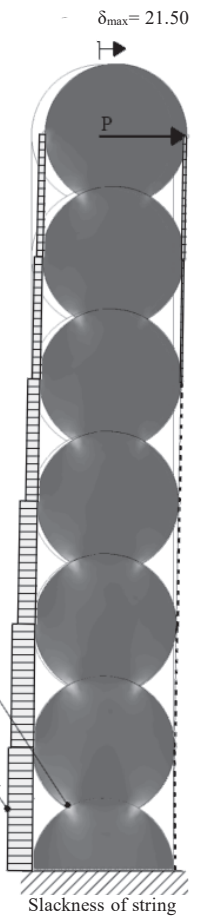

Fig. 16 Comparison of the performance

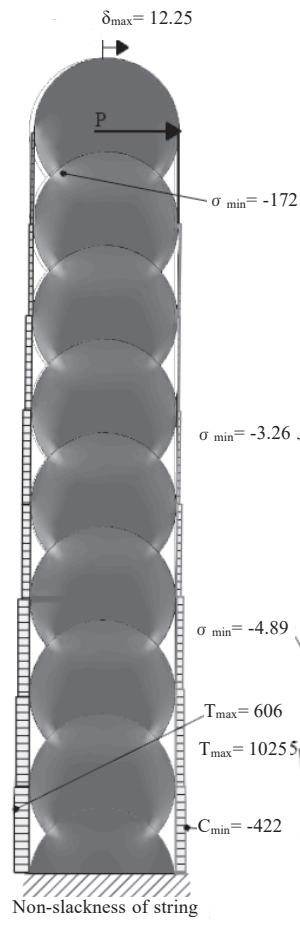

(c) $\mathrm{v}=100^{\circ}$
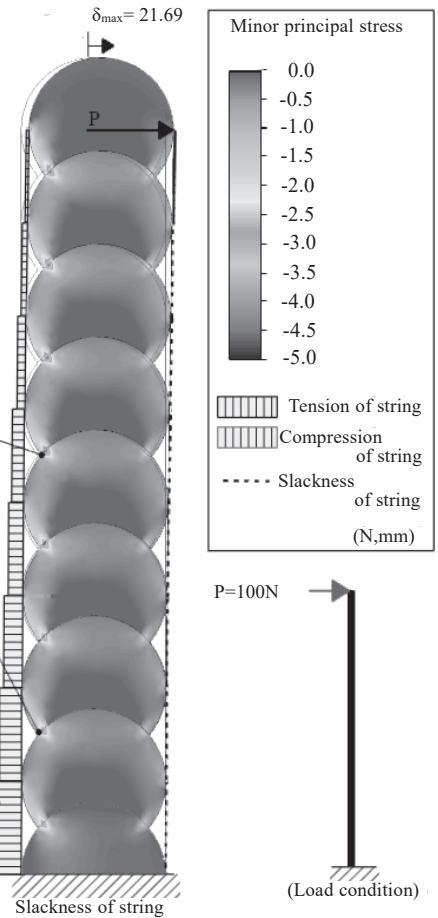

$\mathrm{P}=100 \mathrm{~N}$

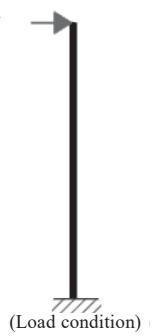


縮応力度では (b)の方が抑えられる。以上, 接合部数, 応力状態, 剛 性に対する角度 $の$ 影響を検討した結果, 適正な角度 $v=60^{\circ}$ である 事を結論付けられる。

\section{C 部品の中空形状の決定とアーム材の役割}

\section{1 C 部品の中空形状}

SCS の軽量化の手段として, 基本形状内に中空部を配置させる。C 部品の構成材の一つ「縦材」の本数および配置形状が SCS 全体の軽 量性や曲げ岡性に与える影響を及ぼす可能性があり，これを明らか にする為にに実験かつ解析的検討を行う。

\section{2 実験解析概要}

C 部品の中心部から放射状に伸びる縦材の本数の違いによって, 12 本の Mode1 A と 2 本の Mode1 B といった 2 種類の C 部品を用いる (Fig. 17 (a))。両者に側面材の外径寸法 (半径 $r=100 \mathrm{~mm}$ ) と C 部品の重 量 $(300 \mathrm{~g})$ を設定し，この共通点から C 部品における側面材と縦材等 の厚さを算定し, Mode1 A には $3 \mathrm{~mm}$, Mode1 B には $7 \mathrm{~mm}$ を指定した。 $\mathrm{C}$ 部品の材料のアルミ合金が前提であるが，本論では各材の最適な 寸法が決まっていず，高価なアルミ合金の使用は得策ではなく，こ の代替材としてエポキシ樹脂を用いる。エポキシ樹脂製の C 部品の 作成方法は次の通りとなる。熱積層式 $3 \mathrm{D}$ プリンタ (積層厚 $=0.2 \mathrm{~mm}$, 造形材料：PLA）でC 部品の型枠を造形し，この型枠内にスリーボン ド社の 2 液性エポキシ樹脂 (主剂 TB2022 : 硬化剂 TB2105C=2 :1) を流 し込み, エポキシ樹脂が固化した後, 型枠を剥がして C 部品を完成 させる。室温等の養生環境や 2 液の調合比率の誤差等によって, エ ポキシ樹脂のヤング係数が変化する事が考えられる。これを確認す る為に，年度毎に単純梁形状のエポキシ樹脂製試験体を製作し，2 点載荷実験を行った。この結果としての材料諸元を Fig18 に示す。

$\mathrm{C}$ 部品の個数を 3 ユニットとし, エポキシ樹脂製の半円形状の支 持部品の上に積み上げ, 弦材の取付による安定化を図った (Fig. 17)。 弦材の PS の存在が SCS 全体の曲げ剛性の変化の原因となり, C 部品
の形状の違いによる構造挙動の比較が純粋に行えない可能性があり, この対策として，「接合部に隙間やルーズホールを設けない」「PS 導入を行わない」を前提にステンレス合金 SUS304の帯形材 $(10 \mathrm{~mm} \times$ 0. $3 \mathrm{~mm}$ )の長さ (ボルト穴間距離 $=151 \mathrm{~mm}$ ) が指定された弦材を用いる (Fig. 17 ( c ))。荷重条件は, 載荷 1 点の水平方向の集中荷重 (最大荷 重 $\mathrm{P}=83 \mathrm{~N})$ とする。載荷ケーブル端部に分銅を載荷すると, 同時に水 平方向の張力が発生し, その張力が $\mathrm{C}$ 部品の最上ユニットの接合金 具に作用する集中荷重となる (Fig. 17 (b))。

\section{3 数值解析概要}

Fig. 19 に解析モデルを示す。これは, 3.3 で述べた接触要素パラ メータおよびFig. 18 に示寸材料諸元による C 部品の $2 \mathrm{D}$ モデルと, ヤング係数 $\left(\mathrm{E}=1.95 \times 10^{5} \mathrm{~N} / \mathrm{mm}^{2}\right)$ および断面積 $\left(3 \mathrm{~mm}^{2}\right)$ による弦材 $($ トラ ス要素) とに構成されている。トラス要素には, 弦材の座屈応力度 (才 イラー式による座屈応力度 $\left.\sigma_{\mathrm{cr}}=-0.63 \mathrm{~N} / \mathrm{mm}^{2}\right)$ が考慮されている。

\section{4 実験および解析結果}

載荷点付近の水平変位量に関する実験および解析の結果を Fig. 20 に示す。実験の結果, 荷重 $\mathrm{P}=20 \mathrm{~N}$ に達するまでに, Mode1 A とMode1 B にそれぞれ $2 \mathrm{~mm}, 7 \mathrm{~mm}$ の水平変位量が発生した。この原因 として，側面材の優劣弧部との接触面に隙間が存在した為に，接触 面の初期滑りが生じた事があげられる。初期滑り後の変位増分量に おいて, 実験と解析と両方ともMode1 A の方が剛性が大きく, C 部

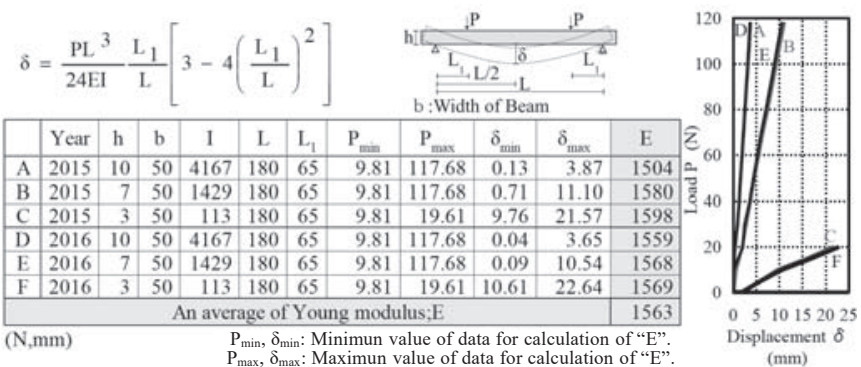

Fig.18 Specifications of epoxy for Crescent part

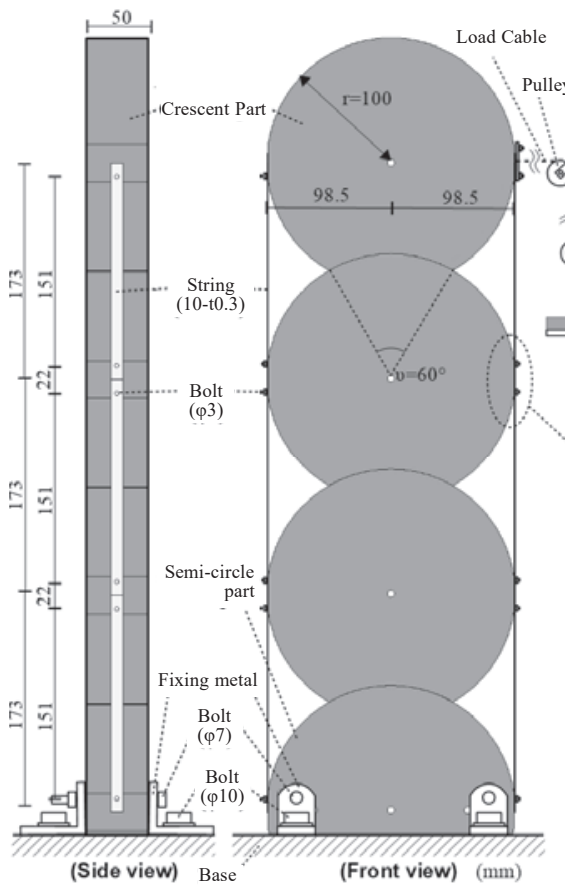

(b)The experimental model \& Loading device Fig.17 Outlines of Experiment

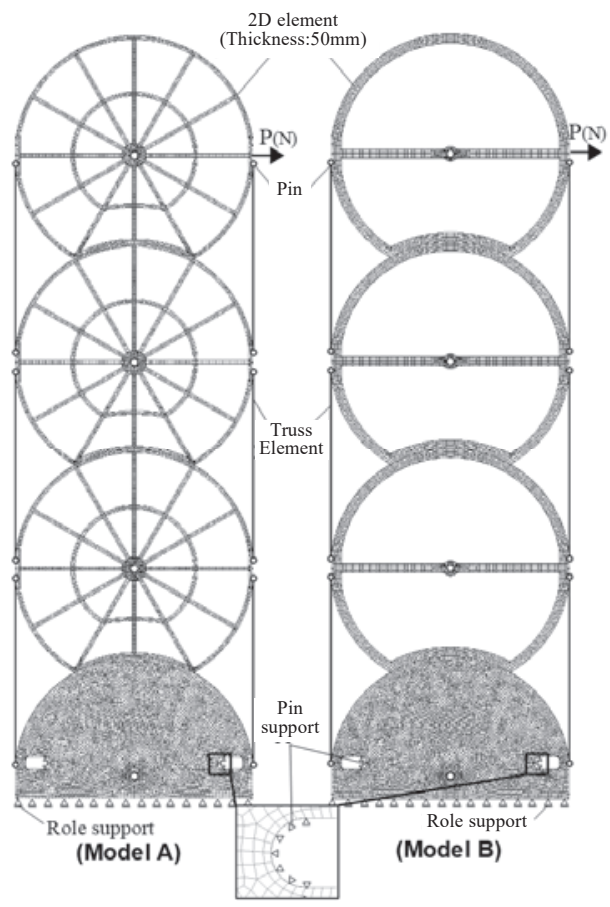

Fig.19 Analysis Model 
品の縦材本数が, SCS の剛性に影響を及ぼす事が確認された。初期 滑り後の試験材の変位増分量において, Mode1 A では実験值と解析 值とほぼ一致した。これに対して, Mode1 B では実験の方が荷重増 分量が抑制された。この原因としては次のように推定される。摩擦 力無の解析モデルと比べて, 試験材では C 部品間の摩擦が発生し, 滑りが抑制される。Fig. 21 に荷重 $\mathrm{P}=83 \mathrm{~N}$ 時の SCS の変形を示す。両 者とも圧縮側の弦材に座屈が生じたにも関わらず，SCS 全体の安定 性が失われなかった。なお, Mode1B の方が弦材の座屈変形が大きく, C 部品の形状の選択が座屈に及ぼす影響がある事を確認できた。応 力度に関しては, Mode1 A と Mode1 B 両方とも，C 部材間の不安定な 応力伝達状態をもたらしており, データの定量化が困難であった為, 本論では各部材のひずみ測定結果を取り上げない。

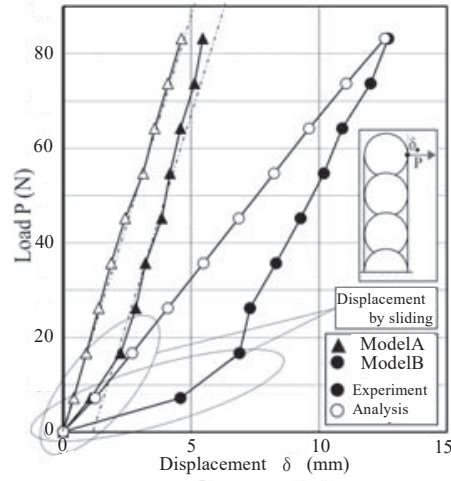

Fig.20 Load-Displacement

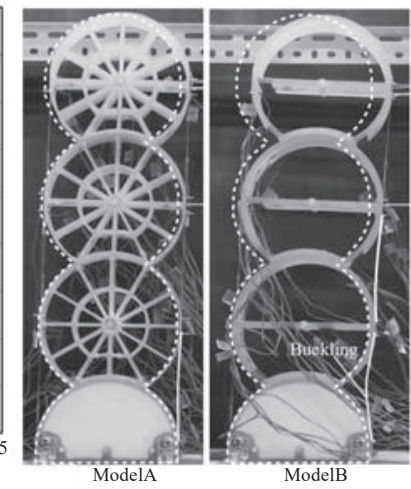

Fig.21 Deformation of SCS

\section{5 アーム材のカ学的な役割}

安定状態の SCS におけるアーム材の役割は, 応力負担等力学的な 役割を有する事が考えられる。この条件として，アーム材のボルト 穴がボルトに接触する必要がある (Fig. 22 (a))。Fig. 17 に示す Mode1 A アアーム材を取り付けて 1 点集中荷重による載荷実験を行ったが， ルーズホールの存在の為, アーム材の力学的な効果が明確ではなか った。そこでルーズホールを設けない条件に, Fig. 19 に示す Mode1 A の解析モデルにアーム材のトラス要素を追加して解析検討を行った (Fig. 22(b))。アーム材の有無による SCS の解析結果を Fig. 23 に示 す。アーム材有の方が変形を抑えられるが，C部品および弦材の発 生応力に差異は見られなかった。これにより, アーム材は，ボルト との接触後の SCS の変形抑制のみ寄与寸る事が伺える。これ以外に 考えられるアーム材の力学的役割は下の通りであり, より詳細なア 一ム材の力学的検討が今後の課題となる。

(1) 弦材の破断時の安全対策

(2) 弦材方向の引張力とせん断方向の力との同時作用による SCS の不安定化対策

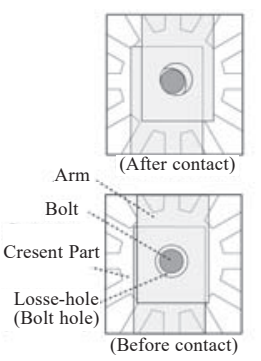

(a) Contact in Loose-hole

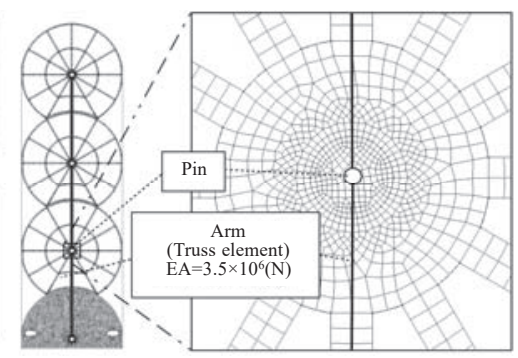

(b) Analysis Model
Fig.22 Joint between Arms and Crescent Parts
（1）に関しては，引張側の弦材が破断した時，同時に SCS が瞬時に分 解され, 避難時間を与えない突然の破壊現象が危惧される。この破 壊の進行を遅らせる手段としてアーム材を予め取り付けておく。

(2)に関しては, 弦材方向の引張力により, C 部品間接触面全体に離 間が生じ，同時に発生したせん断方向の力に抵抗できなくなり，不 安定な状態が発生する事が危惧される。この対策として，不測の離 間の進行を防ぎ，安定性を維持する為に，アーム材を取付ける。さ らに，アーム材のルーズホールの大きさの上限を設け，アーム材お よび弦材の剛性を確保する必要がある。

\section{PS 導入を考慮した SCS の構造挙動}

\subsection{SCS のPS 導入の役割}

4 章の載荷実験では, 長さ指定の弦材を用いた結果, 初期滑りに よる変形が生じる事が明らかとなった。この解決手段として，C 部 品間の隙間等を防止し, 構造挙動の安定性を確保する為に, PS 導入 を行う。これによる PS 効果を把握する為に, 実験解析的検討を行う。

\section{2 実験解析概要}

C 部品の形状および材料諸元は Fig. 17 で示した通りである。弦材 の接合金具には弦材貫通穴を設けたアルミ合金の T 形材を用い， C 部品扁平部にボルトで取り付けた (Fig. 24(b))。載荷条件に関しては 4.2 に示したものと同様と寸る。最大荷重 $\mathrm{P}=90 \mathrm{~N}$ 時の SCS の弦材張 力量を $500 \mathrm{~N}$ と仮定し, ストランドケーブル ( $\phi 1.5)$ の引張実験 (最大 引張力 $800 \mathrm{~N}$ ) を行った。その結果から, Fig. 25 の材料諸元に示すヤ ング係数の算定を行った。ストランドケーブル支持部および PS 導入 装置をFig. 24 (c) に示す。PS 導入前に，全ての接合金具の穴をス卜 ランドケーブルを通し, 架台の下へ吊り下げた全てのストランドケ ーブルの先端に目標 PS に応じた重量の分銅を載せる。目標 PS に達 した後，全ての接合金具毎に設置されたサーキュラースリーブでス トランドケーブルを固定する。以上の作業により得られた PS 導入量 $(=10 \mathrm{~N}, 35 \mathrm{~N}, 70 \mathrm{~N}, 100 \mathrm{~N})$ 毎の応力 変形の変化を把握寸る為に実験かつ 解析的検討を行った。

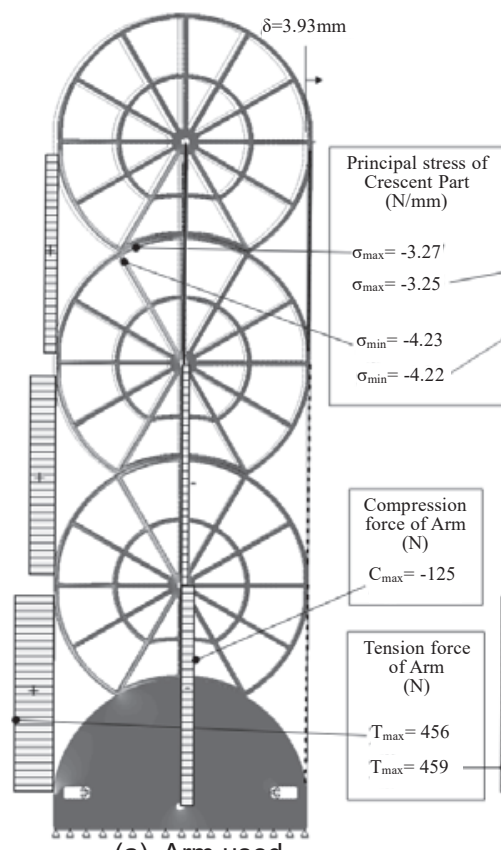

(a) Arm used

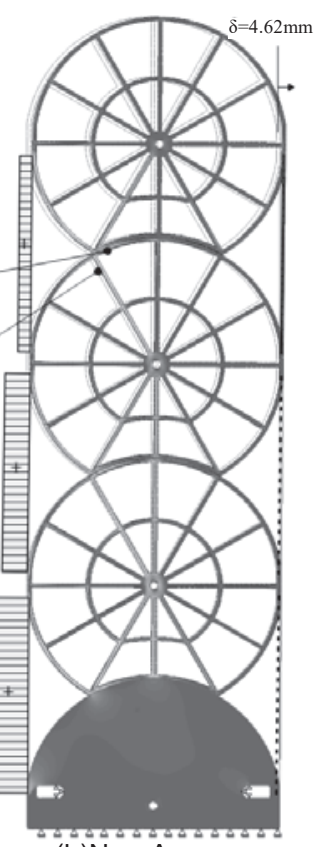

(b)Non-Arm
Fig.23 Analysis result 


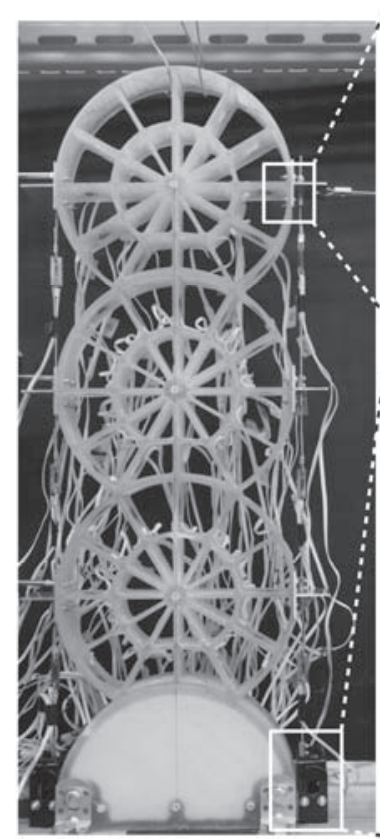

(a)The experimental model

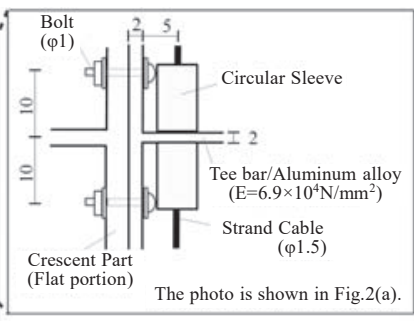

(b) Joint

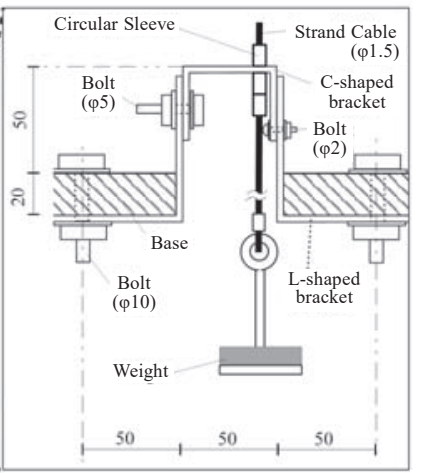

(c) Control unit of PS

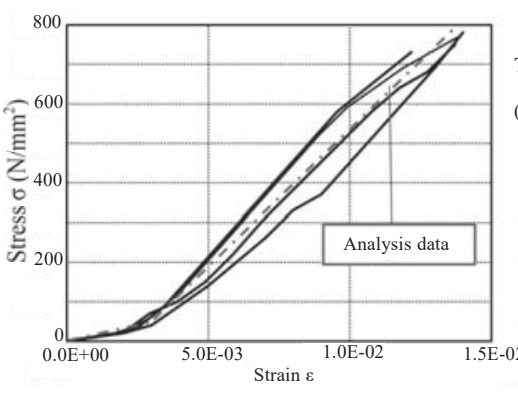

Fig.25 Specifications of Strand Cable

\section{3 実験および解析結果}

SCS の水平変位量を Fig. 26 に示す。載荷実験の結果, PS 量の増大 に伴って水平変位量が抑えられただけでなく, Fig. 20 に示す初期滑 りによる変形も発生しておらず，変位抑制およびSCS の安定性向上 に対する PS 効果が確認できた。ただし, 弦材の張力消失後の変位増 分量は, PS 量に関わらず差異は見られなかった。 SCS の弦材張力の 発生量をFig. 27 に示す。PS 量に関わらず, 弦材の発生張力量の低 減は見られていないが, 弦材の張力消失時の荷重レベルは増加した。 これらの傾向は, 解析結果とほぼ一致している。PS=10N 時の載荷点 付近の弦材 (圧縮側) は一度張力消失が発生したものの, 荷重 $\mathrm{P}=50 \mathrm{~N}$ を超えると再び張力が発生した。この現象は解析結果にも見られて おり，この原因としてFig. 9 に示すせん断力伝達メカニズムと関連 づけられる。PS $=100 \mathrm{~N}$ および荷重 $\mathrm{P}=90 \mathrm{~N}$ 時の SCS の最小主応力状態 をFig. 28 に示す。実験時ひずみ測定点に該当する位置に, PS $=100 \mathrm{~N}$ および荷重 $\mathrm{P}=90 \mathrm{~N}$ 時の解析結果による応力度の印 (圧縮 : $\square$, 引張 : ○, 無応力： $\triangle$ ) を書き入れ,それから， $\triangle$ 印の部材を全て取り除く と，片持卜ラスのような応力状態となる。発生応力が大きい主要な 部材 (1)〜 (9)を選び，ひずタ測定点毎の断面積を最小主応力度また は最大主応力度に乗じて, 圧縮応力または引張応力を算定し, 実験 值と解析值との比較を行った。この結果, 軸力の正負は一致したも のの, 数值のばらつきがみられており, この原因として試験材の初
期不整等が推定される。負方向の軸力 (最大圧縮応力) が生じた主要 な部材 (7) の PS 導入効果を Fig. 29 に示す。PS 量に関わらず, 部材 (7) の発生圧縮応力の低減が見られず, 解析值と実験值と一致している。 この結果は, Fig. 28 に示す主要な部材 (1)〜 (9) においても同様の傾 向が見られる。結論として, PS の役割としては, 初期滑り防止, SCS

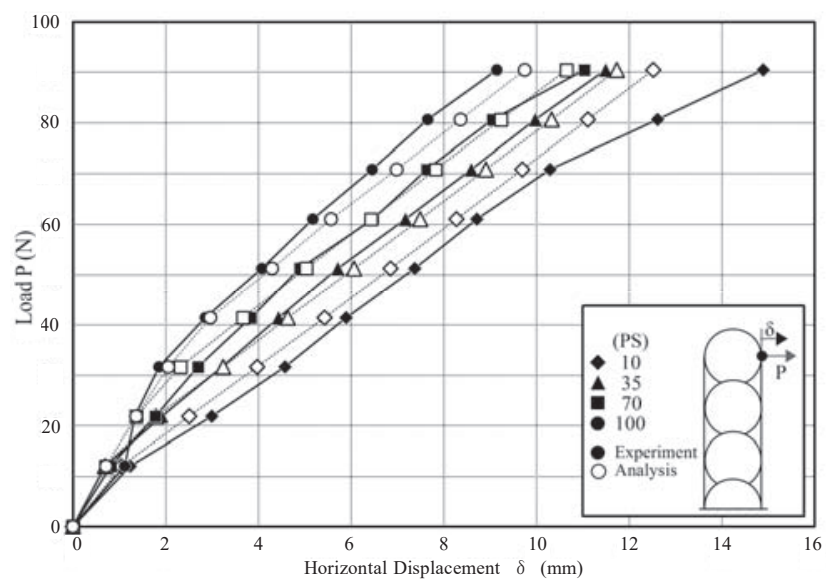

Fig.26 PS-effect : Displacement
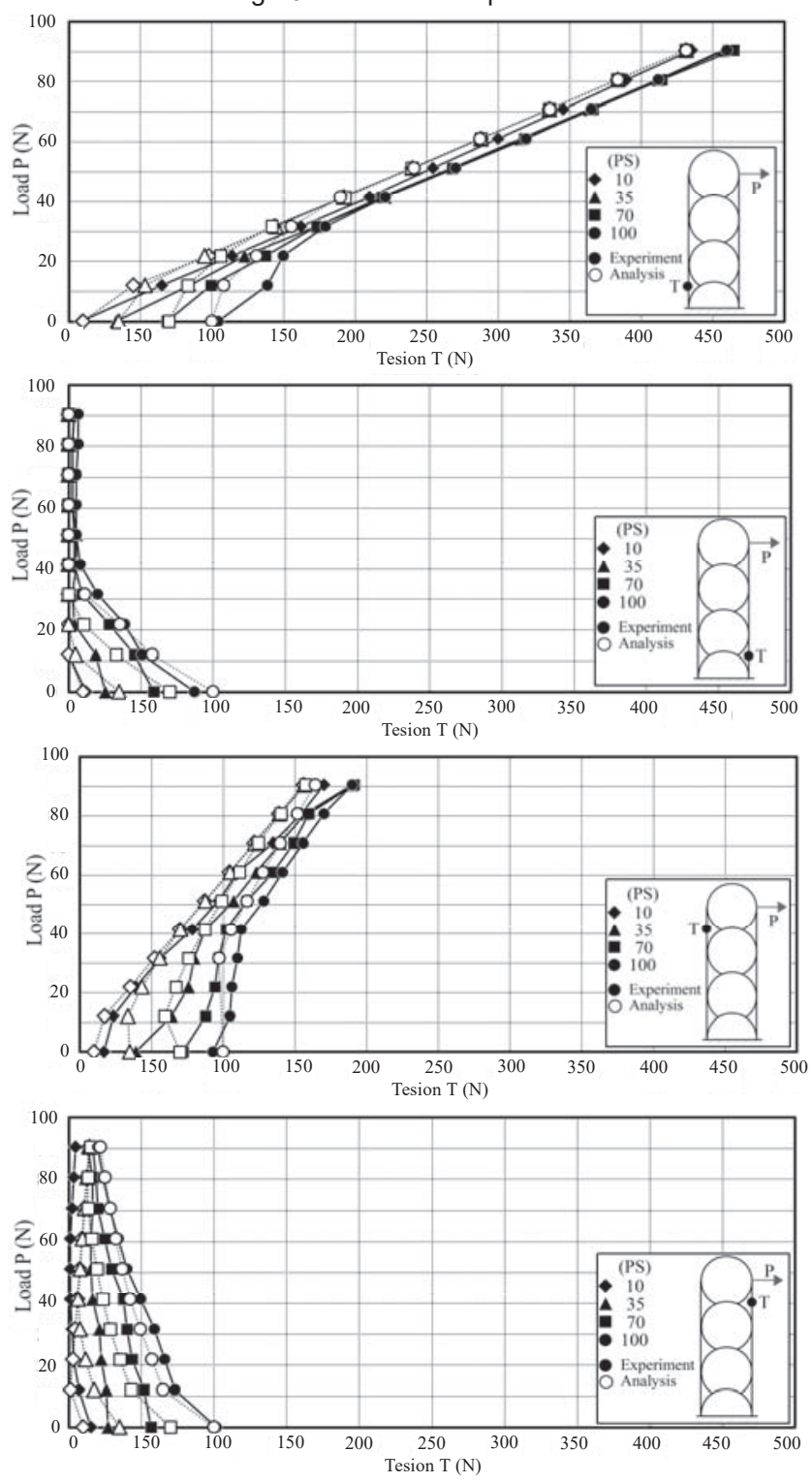

Fig.27 PS-effect : Tension of String 
の安定化, 曲げ剛性の向上, 張力消失時の荷重レベルの向上に寄与 する事があげられる。

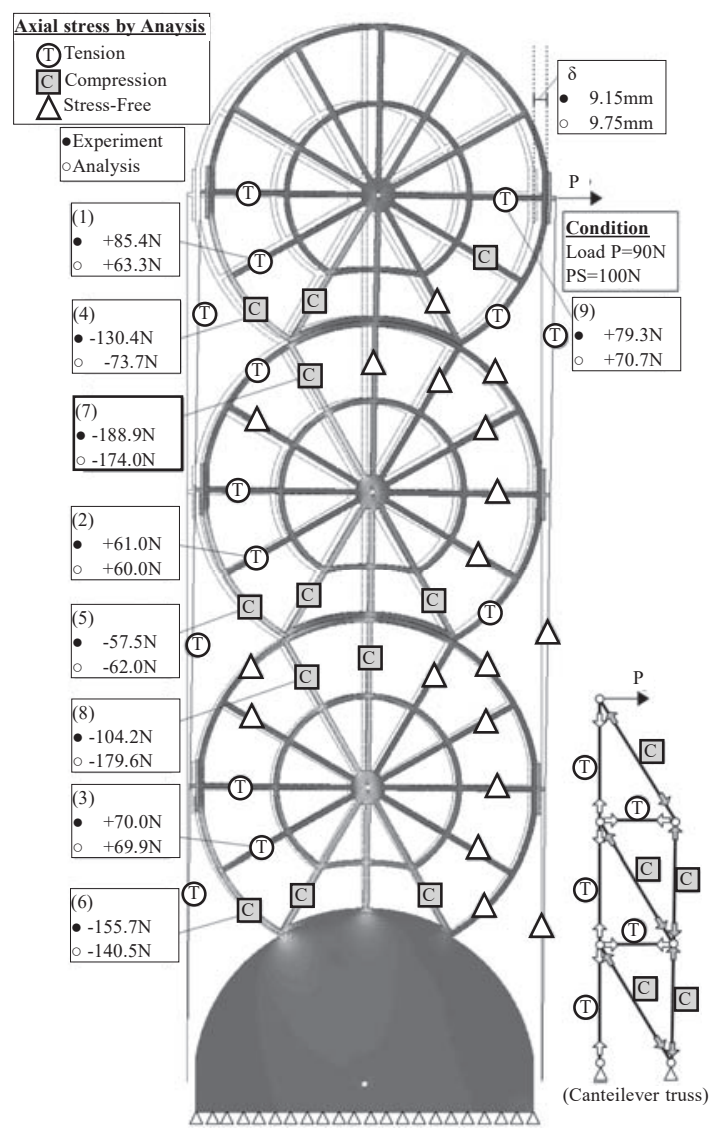

Fig.28 Stress of SCS

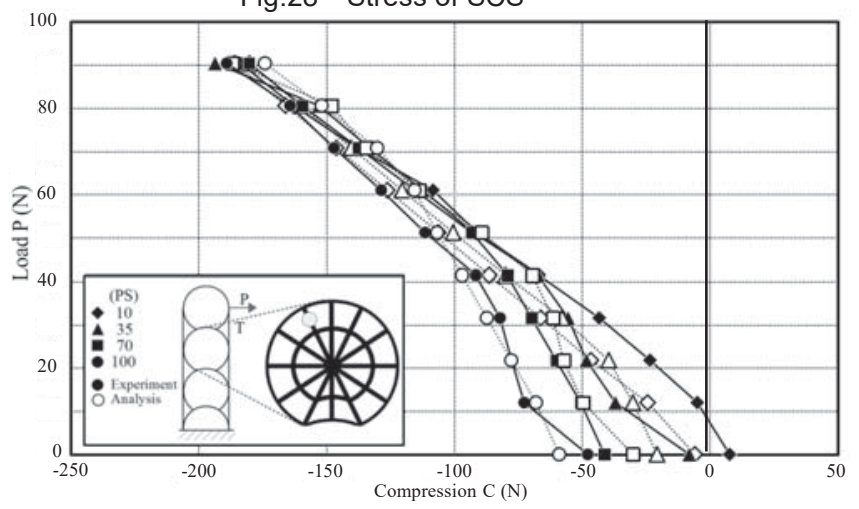

Fig.29 PS-effect : Compression of Crescent part

6 まとめ

リユースシステムの一つ, クレセントシステムを提案し, クレセ ントシステムの安定化を目的に弦材を付加した SCS の構造挙動の検 討を行った結果，次のような知見が得られた。

（1）せん断伝達メカニズムに関して，C部品間の離間の進行を抑え る為に, 圧縮側の弦材にわずかな張力が発生する事を, 実験お よび解析により裏付ける事ができた。

(2) 曲げ伝達メカニズムに関して, C 部品間の回転方向の滑りを抑 える為に 2 弦材の軸力が発生し, 圧縮側の弦材の張力消失が発 生すると, 引張側の弦材の張力増分量が増大寸る。

(3) 変形と $\mathrm{C}$ 部品の応力と弦材軸力と, スパンあたりの接合部数之 のバランスを検討した結果, 適正な角度りを推定できた。
(4) C 部品の中空形状の選択が, SCS の曲げ剛性に影響を与える。

(5) ボルトとの接触後のアーム材の力学的な役割は SCS の変位抑 制への寄与である。

(6) PS の役割は, 初期滑りの防止によるSCS の安定性, 曲げ剛性 および張力消失時の荷重レベルの向上に寄与する。

今後の課題については次の通りとなる。弦材方向の引張力とせん 断方向の力が同時に作用すると, C 部品間の離間が大きくなり不安 定になる事が危惧される。この対策として, ルーズホールの抑制や 剛性の確保を考慮したアーム材等を科学的に検証する。SCS のアー チ形状一の適用が考えられるが, C 部品の縦材と隣接する C 部品の 縦材との材軸上の幾何学的なずれが発生し, 接触面周辺の応力状態 の変化や SCS の剛性低下を及ぼす事が推定される。この対策として 縦材と側面材等との適正な剛性比を検討する。PS 導入手順等の選択 によって優劣弧部間の摩擦や接触の発生状態が変化し, PS 量の制御 の難易度に影響する事が予想され，適正な PS 導入手法を検討する。 これらの課題を解決する事が, クレセントシステムのリユースシス テムへの実用性を高める条件のひとつとなる。

\section{参考文献}

1) Atsushi Ito, Study on Construction of Recycling System of Building Materials in the sight of Market Formation Process, Master's thesis, Dept. of Socio-Cultural Environmental Studies Grad. Sch. of Frontier Sci., Univ. of Tokyo, 2016. 9. 16

2) Haruka YOSHIBA, Tsuyoshi SEIKE, et al. : RESEARCH ON REMOVING AND RECONSTRUCTION OF TEMPORARY HOUSES IN FUKUSHIMA, AIJ J. Technol. Des. Vol. 20, No. 44, 33-38, 2014. 2

3) Akira TANAKA, Masao SAITOH, et al. : STRUCTURAL BEHAVIOUR OF VAUT ROOF UNDER WIND LOADS CONSIDERING CONSTRUCTION, Journal of Structural and Construction Engineering (Transactions of AIJ), No. 611, pp. 95-102, 2007. 1

4) Yasunori MATSUFUJI, et al. : Prestress Distribution in the Wall by Unbond Masonry Construction Method for Sustainable Structure System, of Architecture and Urban Design, Kyushu University, No. 2, PP. 79-87, 2002.7

5) Toyo ITO, et al. : The building \& the construction(建築物と建築方法), JP-A No. 2007-120207

6) Kazushi NAKAMURA : A Easy Visual Guide to Movement and Mechanism of Muscles and Joints, SHUWA SYSTEM CO., LTD, ISBN4798025321, pp. 43, 2010

7) SankyoTateyama Inc. : Size of extruded material (押出形材製造範囲), available from〈http://material.st-grp.co.jp/technology/aluminum/range/index.html〉, (accessed 2017.9. 2)

8) Norihide IMAGAWA, Akira OKADA : Timber Companion, Kenchiku Gijutu,.Inc., ISBN4767700485, p. 15, 1997

9) Digital manual for AUTODESK SIMULATION MECHANICAL 2017: "Simulation Mechanical Surface Contact Options (Nonlinear)"-“Advanced Tab" : available from〈http:/help.autodesk.com/view/ASMECH/2017/ENU/?guid= GUID-489F3645-31BE-43D4-8992-6E8C181B38BA〉,(accessed 2017.9.2).

10) Makoto MOCHIZUKI : Structure in Architecture, GAKKENSHA, ISBN4762360503, pp. 78-81, 1991

11) Kazushi NAKAMURA : A Easy Visual Guide to Movement and Mechanism of Muscles and Joints, SHUWA SYSTEM CO.,LTD, ISBN4798025321, pp. 41, 2010

12) Akira TANAKA : Experimental study of String Crescent Structure (part1), Summaries of Technical Papers of Annual Meeting, Architectural Institute of Japan, Struct.-I, pp. 1003-1004, 2016

13) Akira TANAKA : Study on Structural Characteristics of String Crescent Structure (part2), Summaries of Technical Papers of Annual Meeting, Architectural Institute of Japan, Struct.-I, pp. 1105-1106, 2013

14) Akira TANAKA : Study on Structural Characteristics of String Crescent Structure (part1), Summaries of Technical Papers of Annual Meeting, Architectural Institute of Japan, Struct.-I, pp. 821-822, 2012

15) Akira TANAKA : The building unit, the structure and the construction(建築ユニ ット・建築構造物及び建築方法) , Japanese Patent No. 6078251 


\title{
EXPERIMENTAL STUDY ON THE STATIC CHARACTERISTICS \\ OF STRING CRESCENT STRUCTURE MADE FROM REUSABLE PARTS
}

\author{
Akira TANAKA* \\ * Lect., Faculty of Industrial Technology, Tsukuba University of Technology, Dr.Eng.
}

In this paper, a prerequisite for "Reuse System" is that building materials finish the design of the reuse part before production. This use is temporary space, indoor exhibitions, the store in commercial facilities. The characteristic of existing reuse systems are "lightness", "rapidity"and "simplicity", but existing reuse systems is not combined "The kind of the use material is minimized" with "The use material is convert to a wide variety of structural shape".

To solve this problem, I propose Crescent System. Crescent System is the structure that Crescent Parts were connected by the arms. The joint of Crescent System combines "Mobile joint with the arms"and "Unbonding joint with Crescent Parts". Crescent Part is Aluminum extrusions, this basic shape is crescent-shape that was made in Major arc and Minor arc. This change of basic shape affects the small dimensions of Crescent System. I made the miniature. As a result of this, a wide variety of shape was able to formed by the arms and Crescent Parts only. This Crescent System was stable by the installation of the strings. This stable structure is String Crescent Structure (SCS). I did an experiment and analysis to study structure behavior of SCS. As a result of this study, the knowledges were shown below.

* Shear transfer mechanism between Crescent Parts:

(Non-separating) The tensions of the strings does not occur, and the bearing stress occur.

(After separating) The tensions of two strings reduce the separating between two Crescent Parts, and bearing stress increase.

*Bearing moment transfer mechanism between Crescent Parts:

(Non-slackness) Compression force occurs to one string, and tension force to the other string. Bearing stress between two Crescent Parts is small.

(After slackness) Slackness occurs to one string, and tension force of the other string increase. Bearing stress between two Crescent Parts increase too.

*The change of Crescent part-shape influences compared rigidity, compression stress of the string and Crescent Part.

*The selection of the hollow structure for Crescent Part influences the rigidity of SCS.

*A mechanical role of arms contact to the bolts is only the reduction of deformation.

*A mechanical role of the prestress of the strings is prevention of deformation by slide, stabilization of structural behavior and the increment of the rigidity and the load for the slackness of the strings.

The direct joining between Crescent Parts is "Unbonding joint" to permit siding and separating. As a result, I expected that SCS shows the structure behavior different from the elastic continuum, and put the case that the experimental value is different from the analysis value. However, the experimental value accorded with the analysis value in "Load-displacement"and "Load-tension of the string".

The challenges for the future are as follows. When SCS is applied into a an arched form, the two material axes of Crescent Parts are not aligned in a straight line. This geometric problem may influence rigid reduction, the increase of the stress. To prepare for this, I examine the appropriate value of the rigid ratio of each material for Crescent Part. The change of the prestress installation process influences the position and the size of friction and the contact in "Unbonding joint". This phenomenon may make the prestress control difficult. To prepare for this, It is necessary to study the prestress installation process and joint detail of the string. These problem solution is the condition of the utility improvement of Crescent System. 